\title{
Theorizing mobility through concepts and figures
}

\author{
Noel B. Salazar*
}

\begin{abstract}
If Enlightenment thought introduced the study of a common humankind and an anthropology of its diverse states, then it is mobility - as the traversal of boundaries - that implicitly lays the ground of a modern knowledge system. DUBOw (2004, p. 217).
\end{abstract}

As a concept, mobility captures the common impression that one's lifeworld is in flux, with not only people, but also cultures, objects, capital, businesses, services, diseases, media, images, information, and ideas circulating across (and even beyond) the planet. History tells us the complex story of human mobility - a complex assemblage of movement, social imaginaries, and experience (Cresswell, 2006). People across the globe have long been interconnected, populations have been mobile, and their identities have often been fluid, multiple, and contextualized. It is important to acknowledge the various (historical) forms that mobility has taken, because the ways people move exert strong influences on their culture and society (Casimir and Rao, 1992).

The scholarly literature is replete with metaphors trying to describe (perceived) altered spatial and temporal movements: deterritorialization, reterritorialization, and scapes (Appadurai, 1996); time-space compression (Harvey, 1989), distantiation (Giddens, 1991), or punctuation (Smart and Smart, 2008); the network society and its space of flows (Castells, 2000); the death of distance and the acceleration of modern life (Virilio, 2006); and nomadology (Deleuze and Guattari, 1986). The academic interest in mobility goes hand in hand with theoretical approaches that reject a "sedentarist metaphysics" (Malkki, 1992) in favor of a "nomadic metaphysics" (Cresswell, 2006) and empirical studies on the most diverse kinds of mobilities (Adey et al., 2013), questioning earlier taken-for-granted correspondences between

* University of Leuven (Belgium). 
peoples, places, and cultures. The way the term is being used, mobility entails, in its coinage, much more than mere physical motion (Marzloff, 2005). Rather, it is seen as movement infused with both self-ascribed and attributed meanings (Frello, 2008). Put differently, mobility can do little on its own until it is materialized through people, objects, words, and other embodied forms. Importantly, mobility means different things to different people in differing social circumstances (Adey, 2010).

Mobilities are central to the structuring of people's lives. In many parts of the world, mobility is an important way of belonging to today's society. We can identify multiple types of "movers": tourists and pilgrims; migrants and refugees; diplomats, businesspeople, and those working for international organizations; missionaries, NGO workers, and people belonging to the most diverse transnational networks; students, teachers, and researchers; athletes and artists; soldiers and journalists; children and partners (and service personnel) accompanying the aforementioned people; and those in the traffic and transport industries who move people (including themselves) across the globe.

Mobility studies call attention to the myriad ways in which people become part, in highly unequal ways, of multiple networks and linkages. Notwithstanding the many kinds of involuntary or forced movements (mostly linked to situations of conflict, persecution, or environmental threat), the currently dominant discourse across the globe still links mobility to three positively valued characteristics: (1) the ability to move; (2) the ease or freedom of movement; and (3) the tendency to change easily or quickly (Salazar, 2010b; Salazar \& Glick Schiller, 2014; Salazar and Smart, 2011). This translates into three assumptions, partly influenced by neoliberal and capitalist ideologies, which are widely spread via public discourses and images about globalization: (1) there is (increasing) mobility; (2) mobility is a self-evident phenomenon; and (3) movement generates positive change, often conceived of as an improvement for oneself and one's kin (e. g., in the case of migrants) or for nonrelated others (e.g., in the case of NGO workers).

It is important to identify not only various forms of boundary-crossing movement but also the (re)production of socially shared meanings through diverse practices of mobility. Many people link voluntary geographical mobility automatically to a symbolic "moving up," be it economic, social, or cultural. In other words, mobility is believed to be an indicator of the variable access to and accumulation of various types of capital (Bourdieu, 1986). Distinctions are made, which feed back into the production of the social through culturally inflected notions of mobility (e. g., the terms "local" versus "migrant"). Transnational mobility, for instance, is often seen as endemic to globalization and as one of the most powerful stratifying factors, leading to a global hierarchy of movements (Bauman, 1998). In other words, the 
movement of people and their various translocal connections may, and often do, create or reinforce difference and inequality, as well as blending or erasing such differences (Salazar, 2010a).

Mobility is not only an object of study, but also an analytical lens, promoted by those who talk about a mobility turn in social theory and who have proposed a new mobilities paradigm to reorient the ways in which we think about society. This mobility turn indicates a perceived transformation of the social sciences in response to the increasing importance of various forms of movement (Urry, 2000; 2007). The new mobilities paradigm incorporates new ways of theorizing how people, objects, and ideas move around by looking at social phenomena through the lens of movement (Hannam et al., 2006). It is a scholarly critique of both theories of sedentism and deterritorialization.

Influential theorists such as Anthony Giddens, Arjun Appadurai, Ulrich Beck, Manuel Castells, Bruno Latour, David Harvey, Zygmunt Bauman, and John Urry all conceive contemporary capitalism and globalization in terms of increasing numbers and varieties of mobility: the fluid, continuous (and often seamless) movement of people, ideas, and goods through and across space (but see Trouillot, 2003 for a critique). Mobility appears self-evidently central to modernity as a key social process, "a relationship through which the world is lived and understood" (Adey, 2010, p. I). People have come to "imagine that mobility is border crossing, as though borders came first, and mobility, second" (Ludden, 2003, p. 1062). Considering mobility as a natural tendency in society naturalizes it as a fact of life and as a general principle that rarely needs further justification, making reliance on mobility capital the norm. However, any discourse used to discuss questions of mobility is inevitably value-laden (Bergmann and Sager, 2008; Frello, 2008).

Critical analyses of mobility focus attention on the political-economic processes by which people are bounded, emplaced, allowed, or forced to move (Abram et al., 2017; Casas-Cortes et al., 2015; Cunningham and Heyman, 2004). Such studies show how mobility is always materially grounded. The physical movement of people entails not only a measure of economic, social, and cultural mobility, but also a corresponding evolution of institutions and well-determined "circuits of human mobility" (Lindquist, 2009, p. 7). Importantly, the substance of such circuits is "the movement of people (and money, goods, and news, but primarily people) as well as the relative immobility of people who do not travel the circuit" (Rockefeller, 2010, p. 222). To assess the extent or nature of movement, or, indeed, even "observe" it sometimes, one needs to spend a lot of time studying things that stand still (or change at a much slower pace).

Despite all the attention given to it over recent decades, some commentators are of the opinion that "there is still a general failure, especially in the social sciences, 
to reflect on the meaning of mobility" (Papastergiadis, 2010, p. 347). Recognizing that the mobilities the world witnesses today are not entirely new processes, what are we really talking about when we look at the current human condition through an analytical mobility lens? Grounded in anthropology's long-term engagement with issues of mobility (Salazar, 2013b), this article offers some preliminary conceptual reflections surrounding scholarly ideas of mobility. I particularly focus on the scholarly potential offered by the approaches of key concepts and key figures.

\section{Anthropology and (im)mobility}

Ideas of mobility have a long history in anthropology (Salazar, 2013a). They are already present in late nineteenth- and early twentieth-century transcultural diffusionism, which understood the movement of people, objects, and ideas as an essential aspect of cultural life. While classical anthropology tended to ignore or regard boundary-crossing journeys as deviations from normative place-bound communities, cultural homogeneity, and social integration, discourses of globalization and cosmopolitanism (that became dominant since the end of the Cold War) shifted the pendulum in the opposite direction. As Anna Tsing states, the classical type of anthropology constituted cultures "as essentially immobile or as possessing a mobility that is cyclical and repetitive [...] Those with culture are expected to have a regular, delimited occupation of territory. If they move, they must do so cyclically, like transhumant pastoralists or kula-ring sailors" (Tsing, 1993, p. 123). Indeed, mobility was too often limited as a defining characteristic of groups such as hunter-gatherers or traveler-gypsies. It was used as a concept describing physical or abstract movement, not as something implying in and of itself social or cultural change (Farnell, 1999). If older theoretical frameworks were unable to handle interconnection and mobility, this is a problem with the theories, not the mirror of an evolutionary global change (and this critique was also raised by decolonial Latin American authors).

In the 1990s, globalization - theorized in terms of trans-border "flows" - was often promoted as normality, and too much place attachment a digression or resistance against globalizing forces. Mobility became a predominant characteristic of the modern globalized world. This led to a new focus on transnational mobilities that deterritorialize identity. Arjun Appadurai's (1996) provoking notion of "ethnoscapes", for instance, privileges mobile transnational groups and individuals, such as migrants, exiles, tourists, and guest workers ${ }^{1}$. As Aihwa Ong (1999, p.

1. Relevant in this context is that Appadurai proposes that globalization fundamentally alters the "movement" of individuals, technology, money, media, and ideas. 
4) explains, "Trans denotes both moving through space or across lines, as well as changing the nature of something". While globalization studies grew in popularity, anthropologists were for a long time absent in the interdisciplinary discussion around mobility studies ${ }^{2}$.

By the turn of the millennium, there were already serious cracks in the master narrative of unfettered mobility, which accompanied the discourse of the benefits and necessity of (economic) globalization. According to Engseng Ho, who studied the movement of an old diaspora across the Indian Ocean over the past five hundred years, "the new anthropology of mobility has reintroduced a teleology of progress that had previously been derided and, so it seemed, discarded [...] Yet societies, cultures, and religions have been mobile for a long time" (Ho, 2006, p. 10). Anthropologists also questioned the nature of mobility itself because "neglecting the practices that create the objects and processes of mobility leads analysts to miss alternative constructions that seriously challenge neat and teleological narratives of globalization" (Maurer, 2000, p. 688).

The ability to move "freely" is spread very unevenly within countries and across the planet ${ }^{3}$. For the very processes that produce movement and global linkages also promote immobility, exclusion, and disconnection (Cunningham and Heyman, 2004; Salazar and Smart, 2011; Söderström et al., 2013). This presents a serious criticism to the overgeneralized discourse that assumes "without any research to support it that the whole world is on the move, or at least that never have so many people, things and so on been moving across international borders" (Friedman, 2002, p. 33$)^{4}$. Transnational travels remain the exception rather than the norm. Critically engaged anthropologists were among the first to point out that contemporary forms of mobility need not at all signify privilege (Amit, 2007). The boundaries people are faced with are not only related to a lack of resources (mostly economic) but can also be linked to social class, gender, age, lifestyle, ethnicity, nationality, and disability all of which have been discussed by anthropological research in some way or other. In what follows, however, I zoom in on two conceptual approaches.

2. As a reaction to this perceived gap, I founded, in 2009, the Cultural Mobilities Research (CuMoRe) cluster at the University of Leuven. This coincided with the start of the Open Anthropology Cooperative Anthropology and Mobility group, which was institutionalized in 2010 as the EASA Anthropology and Mobility Network (commonly known as AnthroMob).

3. Geographers such as Doreen Massey (1993, p. 62) long pointed to the "politics of mobility and access" and how "the mobility and control of some groups can actively weaken other people".

4. The argument of a general increase in human mobility across time is contested. At the same time, it is undeniable that patterns of mobility are changing, whereby some types of movement may lose ground to others. 
Keywords as an analytical approach

The origin of the notion keyword is sometimes traced to Michel Bréal's Semantics: studies in the science of meaning (1964). This French philologist set out to figure out the laws that govern changes in the meaning of words. It was only later that scholars began to turn their attention to the synchronic study of meaning too. In his seminal work Keywords: a vocabulary of culture and society (1976), Raymond Williams explored the changing meanings and contexts of the pivotal terms used in discussions of culture (beginning with the notion of culture itself). In his introduction, he identified keywords "in two connected senses. They are significant, binding words in certain activities and their interpretation; they are significant, indicative words in certain forms of thought. Certain uses bound together certain ways of seeing culture and society" (Williams, 1976, p. 15). The legacy of the groundbreaking work of Williams on the meaning construction of keywords lives on in the "Keywords Project", a collaborative research initiative of Jesus College, University of Cambridge, and the University of Pittsburgh ${ }^{5}$ and in the publication Key words: Journal of the Raymond Williams Society.

Importantly, keywords are "essentially contested concepts" (Gallie, 1956); that is, they never acquire a closed or final meaning (not even within one domain or discipline). The meaning of a keyword is never settled until it truly disappears from common use or its scholarly paradigm goes into decline. As keywords acquire new meanings, they do not shed old ones. Historically, keywords accumulate meanings, sometimes contradictory ones, and even when one is dominant, others stay available and can be reaffirmed. Moreover, keywords rarely shift their meaning in isolation but do this in conjunction with others. Revising Keywords himself for a second edition, which included twenty-one additional concepts, Williams (1985, p. 27) reaffirmed his "sense of the work as necessarily unfinished and incomplete". The sharing of a word across differing domains of thought and experience was often imperfect, he noted, but this very roughness and partiality indicated that the word brought something significant to discussions of "the central processes of our common life" (Idem, p. 27).

Various scholars have played with the concept of keywords to clarify their theoretical framework. Jean Baudrillard's Passwords (2003) and Gilles Deleuze's 1988-1989 televised Abécédaire (2011) are but two known examples. In August 2011, the Wenner-Gren journal, Current Anthropology, presented a set of articles about keywords in anthropology, namely neoliberal agency, consumption, identity, and flow. In the editorial introduction to the theme, Mark Aldenderfer reminded

\section{See http://keywords.pitt.edu.}


the reader that keywords are often multilayered. While some are "commonly encountered in everyday language," others have "special, more restricted meanings, such as is often the case in their scholarly use" (Aldenderfer, 2011, p. 487). From an academic perspective, it is important "to identify the meanings the term has taken and to show how these meanings are transformed when new intellectual perspectives and paradigms make their appearance" (Idem, p. 487). In the reply to his own contribution in Current Anthropology, David Graeber sketches the history that led to the special section. According to him, it was Lauren Leve's idea "to study those theoretical terms that were not, really, being debated - or often, really, defined - and why" (Graeber, 2011, p. 508).

Mobility as keyword

Is mobility itself an important keyword? Williams did not think so. However, it does appear in the New keywords volume, published thirty years after the original version (Berland, 2005). There, it is described as expressing "different, sometimes contradictory meanings underlying our most fundamental beliefs about progress, freedom, individuation, and power" (Idem, p. 217). Mobility is acknowledged as a key concept in globalization studies, where it is seen as "an overarching consideration rather than any particular theory" (Mooney and Evans, 2007, p. 166). It also appears in the 2013 edition of Theory in social and cultural anthropology (Salazar, 2013b). The journal Cultural Studies showcased an interesting project, entitled "New keywords: migration and borders" (Casas-Cortes et al., 2015). The idea behind this collaborative writing endeavor is to call critical attention to the ever-increasing prominence of migration and borders as key notions for apprehending culture and society in our contemporary (global) present.

While people have always been on the move, human mobilities have been variously valued and interpreted through time and within as well as across cultures and societies. In addition, the sociocultural meanings attached to (im)mobility are very often gendered (Uteng \& Cresswell, 2008). Even though many translocal mobilities have evolved from voluntary opportunities to almost an economic necessity, it is still a widespread idea that much of what is experienced as "freedom" lies in mobility (Bergmann and Sager, 2008). Partly influenced by market-based ideologies, translocal mobilities have become a new stratifying factor, producing a global hierarchy of movements. As more people cross physical and social boundaries, authorities and institutions resort to various infrastructures and regimes of mobility to maintain control (Salazar and Glick Schiller, 2014). This causes multiple frictions with people's motility, their agency to be mobile and to choose whether to move or to stay put 
(Kaufmann et al., 2004). Mobility studies, with its emphasis on agency, capital, regimes, and stratification, enriches current understandings of globalization, transnationalism, political economy, the role of cities, and circulation. Certain key concepts have been used, often by scholars from various disciplines (Adey et al., 2013), but a comprehensive working vocabulary of these has not been fully developed.

In his formative work, Williams recognized that due to certain social forces, "in certain words, tones and rhythms, meanings [were] offered, felt for, tested, confirmed, asserted, qualified, changed" (Williams, 1976, p. 12). He sought meanings to formerly understood words through examination of general discussions and separated disciplines, a process which "posed new questions and suggested new kinds of connection" (Idem, p. 14). The edited volume Keywords of mobility: critical engagements (Salazar and Jayaram, 2016) is an attempt to offer an accessible and readable introduction to some of the central terms and debates that shape the study of mobility today, insisting that those debates can be enhanced by an increased understanding of the genealogies of their structuring terms and the conflicts and disagreements embedded in differing and even contradictory uses of those concepts ${ }^{6}$.

The keywords covered in Salazar and Jayaram's volume are capital, cosmopolitanism, freedom, gender, immobility, infrastructure, motility, and regime. Every chapter has the same basic elements: a brief review of the genealogy of the term, an in-depth conceptual reflection on how the term is used in relation to mobility, and ethnographic examples that illustrate the issues at hand. Wherever possible and relevant, the authors also cross-reference to other keywords. As the chapters show, questions about the meaning of keywords extend beyond language, narrowly construed, and need connecting with a world that is outside text. The book confirms that the creative combination of empirical data with conceptual reflection offers a unique contribution to the scholarly investigation of keywords, whether it is applied to a particular domain (such as mobility) or in general.

\section{Key figures of mobility}

A related methodology to the one of keywords was used by Joshua Barker and Johan Lindquist (2009) in their multi-authored essay "Figures of Indonesian modernity", published in the Cornell-based journal Indonesia (a project that they later expanded to the whole of Southeast Asia (Barker et al., 2014). Inspired by the work of Williams, they propose "key figures" as "particular sites that allow access to ideological formations and their contestations" (Barker \& Lindquist, 2009, p. 
36). Interestingly, many of the figures covered in their article are directly related to mobility: the $T K W$ (Tenaga Kerja Wanita), or overseas female labor migrant, who embodies the contradictions of class and gender mobility; the petugas lapangan, or field agent, who functions as an informal labor recruiter for transnational migrants; and Pak Haji, or Mr. Hajj, who wears the white cap that proclaims he has made the pilgrimage to Mecca.

Such an approach offers an analytical perspective rather than a decisive theory. A figure in general not only connotes a representation of an (ideal-type) person but also a lived experience of a particular kind". After all, a figure is "a real person who also is a symbol that embodies the structures of feeling of a particular time and place" (Lindquist, 2015, p. 163) ${ }^{8}$. Figures act as concept-metaphors, in both daily life and academic discourse, whose ambiguity "orient us towards areas of shared exchange" (Moore, 2004, p. 73). At the same time, figures are potentially more loaded than other concepts in the scholar's toolbox due to the semantic blurring between abstract ideal types (which tend to be oversimplified and misleading) and persons as living beings.

Following Barker and Lindquist's (2009) extension of Williams' approach to "key figures", Jamie Coates and I set out to scrutinize the figures that have been used to conceptualize human mobility (Salazar and Coates, 2017). Figures of mobility act as conceptual shorthand in contemporary scholarly debates, allowing social theorists to relate broad-scale phenomena to the human condition. Figures of mobile people have been used to describe both self and other in the social sciences and humanities for a long time (Peters, 2006). Travel in general has been a dominant metaphor for rational thought from de Montaigne to Rousseau (Van den Abbeele, 1992) and many of the figures commonly used are marked by gender, class, ethnicity and culture (Benhabib amd Resnik, 2009; Braidotti, 1994; Kaplan, 1996)9. This repeated usage highlights how these figures have become "keywords", in the sense of Williams (1976), which typify the vocabulary constituting mobility studies today. We interrogated six key figures that have inspired theorization in mobility research (and beyond): the nomad (Deleuze and Guattari, 1986), the exile (Said, 2000), the pilgrim (Bauman, 1996),

7. Lindquist (2015, p. 162) explains the difference between "figure" (an ethnographically and historically situated example) and "type" (a cross-cultural theoretical exemplar) as follows: "While the figure is contingent on a specific socio-historical context, the type consciously accentuates particular characteristics in order to form the basis for comparison".

8. For an alternative view, see Nail, who defines a figure (in his example "the migrant") "not as a type of person' or fixed identity but a mobile social position or spectrum that people move into and out of under certain social conditions of mobility" (Nail, 2015, p. 235).

9. To get a better grasp of how the concept of travel, in general, has influenced the discipline of anthropology, it is worth comparing the work of Lévi-Strauss (1955) with that of Clifford (1997). 
the tourist (MacCannell, 1976), the pedestrian (De Certeau, 1984) and the flaneur (Benjamin, 1996).

The trope of the "figure" is apt here, given how strongly imaginaries of mobility tend to personify the concept (Salazar, 2011) ${ }^{10}$. Just think of migrants, whose attributed identities are defined by their supposed mobility, while in practice their mobility is often curtailed ${ }^{11}$. The imaginaries attached to key figures are not only influential in academia, they also do their work in policy circles. In the case of the EU, for instance, a small minority of (hyper)mobile Europeans lies at the heart of EU conceptualizations and idealizations of flexible European citizenship. They are highly symbolic of some of the ideas of a unified Europe conceived by the founding fathers of European integration (Favell, 2008). They are not statistically significant enough to alter aggregate social mobility charts, but symbolically the very emblem of the de-nationalized Europe that the EU has enabled. They embody the process, flux, and change that the Eu has released, albeit around the edges of European society.

\section{Discussion}

There is no single model or grand theory that can explain the complexity of mobility, certainly not on a global scale. Mobility studies urgently needs "methodological tools and paradigms which can respond to modern systems of mobility but do not in themselves necessarily reify such systems" (Vergunst, 2011, p. 204). Indeed, the cultural assumptions, meanings, and values attached to (im)mobility need to be empirically problematized rather than assumed (Lubkemann, 2008; Salazar, 2010b). Ideological values attached to human mobility are not limited to the academic or social world and people do not necessarily accept the dominant mobility discourse that is imposed upon them (Salazar and Jayaram, 2016).

The key concepts and key figures approaches, outlined above, show the impossibility of there being one kind of mobility: it depends on what makes people mobile, their relations with the places they come from and those to which or through which they move as well as the reasons that they move. Mobility gains meaning through its embeddedness within societies, culture, politics, and histories (which are themselves,

10. Imaginaries can be defined as socially shared and transmitted representational assemblages that interact with people's personal imaginings and are used as meaning-making and world-shaping devices (Salazar, 2014).

11. The problem most people have with migrants is not related to their mobility (movements back and forth) but to the common assumption that they only move once and are "here" to stay (in the sense of permanent settlement) (Salazar, 2016). The category "migrant" is as problematic as its opposite (Jónsson, 2011). 
to a certain extent, mobile). Alongside gender, class, race, ethnicity, age, nationality, language, religion, lifestyle, disability and geopolitical groupings, mobility has become a key difference- and otherness-producing machine, involving significant inequalities of speed, risk, rights, and status, with both mobile and immobile people being engaged in the construction of complex politics of location and movement (Salazar and Smart, 2011).

Moreover, we need to challenge conceptual orientations built on binaries of difference that have impeded analyses of the interrelationship between mobility and stasis (Salazar and Glick Schiller, 2014). Sociocultural anthropologists are well equipped to challenge the (western) assumptions embedded within much current mobility theory. Founding fathers such as Franz Boas and Bronislaw Malinowski, while missing the extent to which their own epistemological project was predicated on their own mobility, showed how the liminal positioning of anthropologists among the humanities and social sciences, with constant methodological and theoretical boundary crossings, offers promise for a fruitful holistic and grounded ethnographic analysis (Salazar, 2013a). Such an approach can help us answer the important question how closely figures and concepts of mobility must represent ethnographic realities to have analytical power.

\section{Bibliographic References}

Abram, Simone et al. (2017), "The free movement of people around the world would be utopian”. Identities: Global Studies in Culture and Power, 24 (2): 123-155.

Adey, Peter. (2010), Mobility. London, Routledge.

Adey, Peter et al. (eds.). (2013), The Routledge handbook of mobilities. London, Routledge.

Aldenderfer, Mark. (2011), "Editorial: Keywords”. Current Anthropology, 52 (4): 487.

Aмiт, Vered (ed.). (2007), Going first class? New approaches to privileged travel and movement. Oxford, Berghahn.

Appadurai, Arjun. (1996), Modernity at large: cultural dimensions of globalization. Minneapolis, University of Minnesota Press.

BARKer, Joshua et al. (eds.). (2014), Figures of southeast Asian modernity. Honolulu, University of Hawaii Press.

BARKER, Joshua \& LINDQUIST, Johan. (2009), “Figures of Indonesian modernity”. Indonesia, 87: 35-72.

Baudrillard, Jean. (2003), Passwords. New York, Verso.

Bauman, Zygmunt. (1996), “From pilgrim to tourist: or a short history of identity”. In: HaLl, Stuart \& Du GaY, Paul (eds.). Questions of cultural identity. London, Sage, pp. 18-36. 
Bauman, Zygmunt. (1998), Globalization: the human consequences. New York, Columbia University Press.

Benhabib, Seyla \& Resnik, Judith (eds.). (2009), Migrations and mobilities: citizenship, borders, and gender. New York, New York University Press.

Benjamin, Walter. (1996), Selected writings. Cambridge, Belknap.

Bergmann, Sigurd \& SAger, Tore (eds.). (2008), The ethics of mobilities: rethinking place, exclusion, freedom and environment. Aldershot, Ashgate.

Berland, Jody. (2005), “Mobility”. In: Bennett, Tony et al. (eds.). New keywords: a revised vocabulary of culture and society. Malden, Blackwell, pp. 217-219.

Bourdieu, Pierre. (1986), “The forms of capital”. In: Richardson, John G. (ed.). Handbook of theory and research for the sociology of education. Westport, Greenwood, pp. 241-258.

BRAIDOTTI, Rosi. (1994), Nomadic subjects: embodiment and sexual difference in contemporary feminist theory. New York, Columbia University Press.

BrÉAL, Michel. (1964), Semantics: studies in the science of meaning. New York, Dover.

CAsas-Cortes, Maribel et al. (2015), "New keywords: migration and borders". Cultural Studies, 29 (1): 55-87.

CASIMIR, Michael J. \& RAO, Aparna (eds.). (1992), Mobility and territoriality: social and spatial boundaries among foragers, fishers, pastoralists, and peripatetics. New York, Berg.

Castells, Manuel. (2000), The rise of the network society. Oxford, Blackwell.

Clifford, James. (1997), Routes: travel and translation in the late twentieth century. Cambridge, Harvard University Press.

Cresswell, Tim. (2006), On the move: mobility in the modern Western world. London, Routledge.

Cunningham, Hilary \& Heyman, Josiah. (2004), "Introduction: Mobilities and enclosures at borders". Identities: Global Studies in Culture and Power, 11 (3): 289-302.

De Certeau, Michel. (1984), The practice of everyday life. Berkeley, University of California Press.

Deleuze, Gilles \& Guattari, Félix. (1986), Nomadology: the war machine. New York, Semiotext(e).

Duвow, Jessica. (2004), “The mobility of thought: reflections on Blanchot and Benjamin". Interventions: International Journal of Postcolonial Studies, 6 (2): 216-228.

FARNELL, Brenda. (1999), “Moving bodies, acting selves”. Annual Review of Anthropology, 28: 341-373.

FAVELL, Adrian. (2008), Eurostars and Eurocities: free movement and mobility in an integrating Europe. Malden, Blackwell.

Frello, Birgitta. (2008), "Towards a discursive analytics of movement: on the making and unmaking of movement as an object of knowledge". Mobilities, 3 (1): 25-50.

Friedman, Jonathan. (2002), "From roots to routes: tropes for trippers". Anthropological Theory, 2 (1): 21-36. 
Gallie, Walter Bryce. (1956), "Essentially contested concepts". Proceedings of the Aristotelian Society, 56: 167-198.

Giddens, Anthony. (1991), Modernity and self-identity: self and society in the late modern age. Stanford, Stanford University Press.

Graeber, David. (2011), “Consumption”. Current Anthropology, 52 (4): 489-511.

Hannam, Kevin et al. (2006), "Editorial: Mobilities, immobilities and moorings". Mobilities, 1 (1): 1-22.

HARVEY, David. (1989), The condition of postmodernity: an enquiry into the origins of cultural change. Oxford, Blackwell.

Ho, Engseng. (2006), The graves of Tarim: genealogy and mobility across the Indian Ocean. Berkeley, University of California Press.

Jónsson, Gunvor. (2011). "Non-migrant, sedentary, immobile, or 'left behind”? Reflections on the absence of migration". IMI Working Papers, 39.

KaPlan, Caren. (1996), Questions of travel: postmodern discourses of displacement. Durham, Duke University Press.

Kaufmann, Vincent et al. (2004), "Motility: mobility as capital". International Journal of Urban and Regional Research, 28 (4): 745-756.

LÉvi-STrauss, Claude. (1955), Tristes tropiques. Paris, Plon.

LINDQUIST, Johan A. (2009), The anxieties of mobility: migration and tourism in the Indonesian borderlands. Honolulu, University of Hawaii Press.

LINDQUisT, Johan A. (2015), "Of figures and types: brokering knowledge and migration in Indonesia and beyond". Journal of the Royal Anthropological Institute, 21 (1): 162-177.

Lipset, David. (2017), “A mobility lexicon”. Transfers, 7 (2): 126-127.

Lubkemann, Stephen C. (2008), "Involuntary immobility: on a theoretical invisibility in forced migration studies". Journal of Refugee Studies, 21 (4): 454-475.

Ludden, David. (2003), "Maps in the mind and the mobility of Asia”. Journal of Asian Studies, 62 (4): 1057-1078.

MACCANnELl, Dean. (1976), The tourist: a new theory of the leisure class. New York, Schocken.

MALKKI, Liisa H. (1992), "National Geographic: the rooting of peoples and the territorialization of national identity among scholars and refugees". Cultural Anthropology, 7 (1): 24-44.

Marzloff, Bruno. (2005), Mobilités, trajectoires fluides. La Tour d'Aigues, Editions de l'Aube.

Massey, Doreen B. (1993), "Power geometry and a progressive sense of place”. In: BIRD, Jon (ed.). Mapping the futures: local cultures, global change. London, Routledge, pp. 59-69.

Maurer, Bill. (2000), "A fish story: rethinking globalization on Virgin Gorda, British Virgin Islands”. American Ethnologist, 27 (3): 670-701.

Mooney, Annabelle \& Evans, Betsy (eds.). (2007), Globalization: the key concepts. New York, Routledge. 
Moore, Henrietta L. (2004), "Global anxieties: concept-metaphors and pre-theoretical commitments in anthropology". Anthropological Theory, 4 (1): 71-88.

NaIL, Thomas. (2015), The figure of the migrant. Stanford, Stanford University Press.

Nelson, Katie. (2017), “Keywords of mobility: critical engagements (book review)". Refuge, 33 (1): 111-112.

Ong, Aihwa. (1999), Flexible citizenship: the cultural logics of transnationality. Durham, Duke University Press.

Papastergiadis, Nikos. (2010), “Wars of mobility”. European Journal of Social Theory, 13 (3): 343-361.

Peters, John D. (2006), "Exile, nomadism and diaspora: the stakes of mobility in the Western canon”. In: MorRA, Joanne \& SMITH, Marquard (eds.). Visual culture: spaces of visual culture. London, Taylor \& Francis, pp. 17-41.

Rockefeller, Stuart A. (2010), Starting from quirpini: the travels and places of a Bolivian people. Bloomington, Indiana University Press.

SAID, Edward W. (2000), Reflections on exile and other essays. Cambridge, Harvard University Press.

SAlazAr, Noel B. (2010a), Envisioning Eden: mobilizing imaginaries in tourism and beyond. Oxford, Berghahn.

SAlazAr, Noel B. (2010b), “Towards an anthropology of cultural mobilities”. Crossings: Journal of Migration and Culture, 1 (1): 53-68.

Salazar, Noel B. (2011), “Tanzanian migration imaginaries”. In: Cohen, Robin \& Jónsson, Gunvor (eds.). Migration and culture. Cheltenham, Edward Elgar, pp. 673-687.

Salazar, Noel B. (2013a), "Anthropology”. In: Adey, Peter et al. (eds.). The Routledge handbook of mobilities. London, Routledge, pp. 55-63.

Salazar, Noel B. (2013b), “Mobility”. In: McGee, R. Jon \& Warms, Richard L. (eds.). Theory in social and cultural anthropology. Thousand Oaks, Sage, pp. 552-553.

Salazar, Noel B. (2014), "Migrating imaginaries of a better life... until paradise finds you". In: Benson, Michaela \& OsBaldiston, Nicholas (eds.). Understanding lifestyle migration: theoretical approaches to migration and the quest for a better way of life. Basingstoke, Palgrave, pp. 119-138.

Salazar, Noel B. (2016), "Conceptual notes on the freedom of movement and bounded mobilities". In: GuteKunst, Miriam et al. (eds.). Bounded mobilities: ethnographic perspectives on social hierarchies and global inequalities. Bielefeld, Transcript, pp. 283-289.

Salazar, Noel B. \& Coates, Jamie (eds.). (2017), Social Anthropology, 25 (1).

SAlazar, Noel B. \& Glick SCHILler, Nina (eds.). (2014), Regimes of mobility: imaginaries and relationalities of power. London, Routledge.

Salazar, Noel B. \& Jayaram, Kiran (eds.). (2016), Keywords of mobility: critical engagements. Oxford, Berghahn. 
Salazar, Noel B. \& Smart, Alan (eds.). (2011), Global Studies in Culture and Power, 18 (6). SMART, Alan \& SMART, Josephine. (2008), “Time-space punctuation: Hong Kong's border regime and limits on mobility". Pacific Affairs, 81 (2): 175-193.

Söderström, Ola et al. (eds.). (2013), Critical mobilities. London, Routledge.

Trouillot, Michel-Rolph. (2003), Global transformations: anthropology and the modern world. New York, Palgrave Macmillan.

TsING, Anna L. (1993), In the realm of the diamond queen: marginality in an out-of-the-way place. Princeton, Princeton University Press.

URRY, John. (2000), Sociology beyond societies: mobilities for the twenty-first century. London, Routledge.

Urry, John. (2007), Mobilities. Cambridge, Polity.

Uteng, Tanu Priya \& Cresswell, Tim (eds.). (2008), Gendered mobilities. Aldershot, Ashgate.

VAn Den AbBeEle, Georges. (1992), Travel as metaphor: from Montaigne to Rousseau. Minneapolis, University of Minnesota Press.

Vergunst, Jo. (2011), “Technology and technique in a useful ethnography of movement”. Mobilities, 6 (2): 203-219.

Virilio, Paul. (2006), Speed and politics. Los Angeles, Semiotext(e).

Williams, Raymond. (1976), Keywords: a vocabulary of culture and society. New York, Oxford University Press.

Williams, Raymond. (1985), Keywords: a vocabulary of culture and society. New York, Oxford University Press.

\section{Abstract}

Theorizing mobility through concepts and figures

As a concept, mobility captures the common impression that one's lifeworld is in flux, with not only people, but also cultures, objects, capital, businesses, services, diseases, media, images, information, and ideas circulating across (and even beyond) the planet. The scholarly literature is replete with metaphors trying to describe (perceived) altered spatial and temporal movements: deterritorialization, reterritorialization, and scapes; time-space compression, distantiation, or punctuation; the network society and its space of flows; the death of distance and the acceleration of modern life; and nomadology. Scholars have used figures of mobile people, too, from nomads to pilgrims, to describe both self and other in the social sciences and humanities for a long time. Taking the societal implications of various forms of mobility seriously and not as a given, the critical discussion of mobility concepts and figures presented here helps us to assess the analytical purchase of the conceptual perspective of mobility studies to normalize movement within the single category of "mobility."

Keywords: Mobility; Theory; Conceptualization; Figures; Anthropology. 


\section{Resumo}

Teorizando a mobilidade: conceitos e figuras

Como conceito, a mobilidade capta a impressão do senso comum de que o mundo da vida está em fluxo, uma vez que não apenas pessoas, mas também culturas, objetos, capital, negócios, serviços, doenças, mídia, imagens, informações e ideias estariam circulando pelo (e mesmo além) do planeta. A literatura acadêmica está repleta de metáforas que tentam descrever movimentos, no tempo e no espaço, que sofrem alterações (e como tal são percebidos): desterritorizalização, reterritorialização e fluxos; compressão espaço-tempo, distanciamento ou pontuações; sociedade em rede e seus espaços de fluxos; a morte da distância e a aceleração da vida moderna; e nomadologia. Acadêmicos também têm recorrido, há muito, a figuras que remetem a pessoas em movimento, desde nômades até peregrinos, para descrever tanto o self quanto o outro nas ciências sociais e nas humanidades. Ao trazer para o centro da cena as implicações das mobilidades sobre a sociedade, a discussão crítica em torno dos conceitos e figuras de linguagem relativos à mobilidade, aqui apresentados, ajuda-nos a avaliar a aquisição analítica da perspectiva conceitual dos estudos de mobilidade que tentam apreender todo movimento sob a categoria única de "mobilidade". Palavras-chave: Mobilidade; Teoria; Conceituação; Figuras de linguagem; Antropologia.

Texto recebido em 30/12/2017 e aprovado em 16/1/2018.

DOI: $10.11606 / 0103-2070 . t s .2018 .142112$

NOel B. SAlazar, Cultural Mobilities Research (CuMoRe), Faculty of Social Sciences, University of Leuven, Belgium. E-mail: Noel.Salazar@kuleuven.be. 